\title{
Delivering Green Economy in Asia: The Role of Fiscal Instruments
}

\author{
Hari Bansha Dulal ${ }^{1}$, Rajendra Dulal ${ }^{2}$, Pramod Kumar Yadav ${ }^{3}$ \\ ${ }^{1}$ Abt Associates, Bethesda, Maryland, USA; ${ }^{2}$ Wayne State University \\ Detroit, Michigan, USA; ${ }^{3}$ Adani Institute of Infrastructure Management, Ahmedabad, India
}

\begin{abstract}
Asia's ongoing rapid economic growth is successfully lifting millions of poor out of vicious cycle of poverty, but that performance has come at a price. The unprecedented growth that we witness today is also rapidly driving resource consumption to unsustainable levels. Local production and consumption-led growth is causing a considerable increase in external costs such as deforestation, and the knock-on effects such as increased emissions, including greenhouse gas (GHG); depletion of non-renewable resources; pollution of rivers; desertification; flooding and long term climate change. Currently, the region accounts for about $40 \%$ of GHG emissions, which is expected to exacerbate with the ongoing rapid industrialization and urbanization. By 2030, if the business-as-usual scenario persists, Asia's share is expected to rise to almost $50 \%$. Given the rapidly increasing resource use and associated environmental externalities, the governments in the region are becoming increasingly interested in pursuing the transition to a green economy as it helps achieve a better balance between the environment, the economy, and social welfare. Asia, when compared to the economies of other regions, has the highest rate of policy innovations that help transition to a green economy. However, for a region as big as Asia to make timely and sustainable transition to green economy, fiscal instruments that facilitate transition to a green economy will have to be adopted in a sufficiently large scale. In this paper, we look at the fiscal instruments that are currently adopted in Asia and their effectiveness in decoupling economic growth from emissions, pollution, and resource use, and advancing economic and social well-being. We will compare the design characteristics that influence the potential impact of these instruments and outline incentives and strategies needed to tackle the barriers for widespread adoption of effective fiscal instruments.
\end{abstract}

Keywords: Asia, green economy, fiscal instruments, opportunities, barriers

\section{Introduction}

Asia, as a region, is growing at an unprecedented rate and consumption of resources and associated emissions are following a similar trajectory. With ongoing rapid expansion of economy, population, urbanization, and industrialization, there is a consistent increase in resource consumption and associated emissions. Countries are increasingly getting locked-in into carbon-intensive infrastructure development pathways. For instance, two large emerging 
Asian economies: China and India are expected to grow by $7.7 \%$ and $5.9 \%$ per annum in 2014 2018. These figures are significantly higher than projected growth in OECD countries $(2.5 \%$ per annum), World (3.7\% per annum), and USA (3.5\% per annum) in 2014-2015 (OECD, 2014). Sustenance of such a growth rate will exacerbate resources use and emissions, which is already high. The total consumption of oils, biofuels, gas-to- liquids and coal-to-liquids (or total liquids consumption) in Asia increased by $92 \%$ between 2010 and 1990 is expected to further increase by $44 \%$ between 2010 and 2030 . Likewise, between the same period, the total natural gas and total coal consumption is expected to increase by $114 \%$ and $50 \%$, respectively (ADB, 2011). Under the business-as-usual scenario, coal could account for $35-45 \%$ of global net growth in electricity generation over the next two decades. Increase in coal-based energy generation is expected to increase coal consumption from its current level by $50-60 \%$ in the next two decades. The chances of Asia, as a region, getting locked into carbon-intensive pathways is really high, because nearly all of the increase is projected in fast-growing regions of Asia, where coal could account for 50-70\% of new power supply (IEA, 2013). With growing economy and ongoing rapid urbanization the rate of motorization and associated energy use in the transport sector is going further increase. From 20.5 million vehicles, in 2002, the total number of vehicles in China is projected to increase to 390 million by 2030 . China will have more vehicles than any other country: twenty four percent more vehicles than the USA by 2030. The situation will be quite similar in other rapidly growing economies in the region. From 17.4 and 8.1 million vehicles, in 2002, the total number of vehicles in India and Thailand are projected to increase to 156 and 44.6 million by 2030 . This could drive emissions, including GHG to dangerous levels. With 8286.9 and 2008.8 million metric tons, China and India are already among top five GHG emitting countries (World Bank, 2014). It is not only the region's rising emissions and their contribution towards global warming that is concerning, but the impact that increasing emissions are having on local population and economy. Asian cities are among the most polluted cities in the world, India alone has 10 out of 20 most polluted cities. Delhi has the highest level (153 micrograms) of the airborne particulate matter $\mathrm{PM}_{2.5}$, which is considered most harmful to health (WHO, 2014).

Growing economy will further accelerate urban migration and further complicate infrastructure development, resource utilization, and waste management patterns. Approximately, 120,000 people are added to Asian cities every day and 44 million every year (Punte, 2012). By 2015, 15 out of 23 of the world's megacities will be in Asia (UN, 2001b). Given the massive carbon intensive infrastructure development, urbanization, and transport demand and use, the chances of Asian countries getting locked into carbon-intensive pathways appear eminent unless policies are changed, and changed, fairly soon. The growth-related externalities witnessed by Asian countries cannot simply be wished away. With ongoing rapid increase in population, urbanization, and demand and use of resources, costs associated with economic growth and unplanned economic development will continue to increase. The time has come to think "outside the box" and across boundaries in order to get a grip on the impending environmental crisis, which will have adverse socioeconomic and environmental consequences. The green economy provides an alternative paradigm that will help bring about transformational change, without which, solving Asia's growing resources use and contain associated externalities related costs is not possible, if not impossible. Even though greening 
growth entails trade-offs and upfront costs, it provides a real opportunity to address growing environmental and climate change problems and plus achieve co-benefits and efficiency gains.

The transition to a green economy becomes more costly once countries get locked-into carbon intensive pathways. Now is the perfect time to transition to a green economy, as the demand for resources, energy, transport, infrastructure, water, and waste management are all increasing and increasing rapidly, in the region. For rapidly growing economy like India, China, Indonesia, Malaysia transition towards green economy provides an opportunity to reduce negative environmental externalities and sustain/better current economic growth without degrading the natural resource base. Additionally, cities and urban areas, with rapidly growing urban infrastructure need offer unique opportunities to transfer into green economy. By 2020, 8 trillion dollars in infrastructure investment will be needed, and the good news is that about two thirds of the \$8 trillion needed for infrastructure investment will be in the form of new infrastructure (Bhattacharya et. al., 2012). The scale of investment required to bridge Asia's infrastructure gap provides a window of opportunity for low-carbon infrastructure development. The existing deficit should be seen as an opportunity to minimize environmental and financial risks, build resilience, and avoid costly renovations. The lack of infrastructure to deliver basic services is an opportunity for the region to get its infrastructure right. Countries in the region can avoid high levels of local pollution and greenhouse gas emissions lock-in and reduce infrastructure's vulnerability to future climate and natural disaster risks by putting in place climate-resilient and energy-efficient infrastructure. The much needed transition to green economy provides Asian countries with an opportunity to leapfrog traditional growth pathways that today's industrialized countries followed and put them into a higher developmental stage without repeating the "grow first clean up later" trajectory.

\section{Asia's transition towards a green economy}

The countries in the region have begun the transition towards a green economy. The Republic of Korea is at the forefront, when it comes to adopting fiscal instruments that facilitate the transition. The Korean initiative for green economy dates back to August 2008, with President Lee commitment to a green growth strategy. A high level Presidential Committee on Green Growth (PCGG) was formed in 2009. One of the main goals of the strategy is to reduce $\mathrm{CO}_{2}$ emissions down to $473 \mathrm{MtCO}_{2}$-e by 2020 , a reduction of $30 \%$ from the projected $676 \mathrm{MtCO}_{2}$-e under business-as-usual scenario. The overall emission of $\mathrm{CO}_{2}$ in Korea increased by $4.4 \%$ during the period 1990 to 2007 (Mathews, 2012). A stimulus package worth US\$30.7 billion was unveiled in 2008 to support the government's efforts to promote renewable energy resources, energy efficient buildings, low carbon vehicles, expansion of railways, and water and waste management (UNEP, 2009). China's $11^{\text {th }}$ Five-Year Plan for Economic and Social Development (2005-2010) was the key turning point for integrating rapid economic growth with green economy through energy conservation. It invested over 2.1 billion US dollars in main science and technology research programs during its $11^{\text {th }}$ five-year plan. China's current 12th Five-Year Plan (2010-2015) is seen as 'Green Growth Plan' with the main focus of reducing pollution, increasing energy conservation and energy efficiency (TERI, 2014). It is investing US\$468 billion into green key sectors during its $12^{\text {th }}$ five year plan compare to US $\$ 211$ billion in the $11^{\text {th }}$ plan 
(Wang, 2014). In 2008, China announced the Green Stimulus Package strengthening its approach towards green economy. A suit of fiscal instruments are being used in China that will facilitate its transition to a green economy. For example, excise tax, acquisition tax, small and energy saving vehicle subsidy are some of the fiscal instruments used to contain growing externalities, including $\mathrm{CO}_{2}$ emissions in the transport sector (Hui, 2011). State-owned banks in China provide substantial financial support for renewable energy programs. In 2009, the Chinese government spent $\$ 45$ billion in upgrading the electricity grid (Chen, 2009c). Like in China, the government of India has also under taken many policy initiatives, which contributes towards transition to green economy. In India, the government has adopted excise tax and special excise duty to contain $\mathrm{CO}_{2}$ emissions from new passenger vehicle (Hui, 2011). Instead of taxing pollution, the government of India has initiated a tax of Indian Rupees (INR) 50 per metric ton of coal in $\mathbf{2 0 1 0}$ for both domestic and imported coal, collected as duty of excise. The tax is known as Clean Energy Cess and the tax revenue is hypothecated towards promoting and financing clean energy by setting up National Clean Energy Fund and; in the wake of growing financing demand from renewable sector Indian government also raised the tax to 100 per metric ton of coal in 2014 to enlarge the fund size (see table 1).

Table 1. Fiscal revenue from Clean Energy Cess in India (INR Billion)

\begin{tabular}{|c|c|c|c|c|c|c|c|}
\hline & $\begin{array}{l}\text { Actual } \\
2010- \\
2011 \\
\end{array}$ & $\begin{array}{l}\text { Revised } \\
2011- \\
2012\end{array}$ & $\begin{array}{l}\text { Budget } \\
2012- \\
2013\end{array}$ & $\begin{array}{l}\text { Actual } \\
2012- \\
2013 \\
\end{array}$ & $\begin{array}{l}\text { Budget } \\
2013- \\
2014\end{array}$ & $\begin{array}{l}\text { Revised } \\
2013- \\
2014\end{array}$ & $\begin{array}{l}\text { Budget } \\
2014- \\
2015 \\
\end{array}$ \\
\hline Clean Energy Tax & 10.66 & 32.49 & 38.6 & 30.53 & 35.36 & 35.27 & 68.57 \\
\hline $\begin{array}{l}\text { Number of approved clean } \\
\text { projects }\end{array}$ & 0 & 10 & 5 & & & 14 & \\
\hline Total approved Financing size & 0 & 5.73 & 14 & & & & \\
\hline
\end{tabular}

Source: Pandey, Bali, \& Mongia (2013); Union Budget, Government of India, 2014-2015

Besides the national level initiatives from the central government, state governments in India have also come forward with plans to boost solar and other renewable energy initiatives. The states of Rajasthan and Gujarat, for example, have power purchasing agreements (market incentive) for solar power plants up to the year 2025. The state of Tamil Nadu provides a maximum amount of INR 12 per KWH for electricity generated from solar Photovoltaic and INR 10 per $\mathrm{KWH}$ of electricity generated through solar thermal route as an incentive for renewable energy (Shekhar,2013). Fiscal incentives together with state level institutional supports and regulatory measures have enhanced penetration of renewable and increased participation from private sector in India (Schmid, 2012; Sawhney \& Rahul, 2014).

The progress towards transition to a green economy has already begun, however, the troubling aspect of the ongoing progress is that it is concentrated in a few countries (see table 1, annexI). Few countries, especially the ones that are relatively well off are taking the lead towards transition to a green economy and implementing host of fiscal instruments. Least develop countries are yet to adopt instruments beyond the ones that are high revenue generating and administratively simple to implement. What emerges from the table is a broad emphasis on renewable incentive and provisioning of concessional financing by the relatively well-off 
countries in the region. Incentives that reduce cost and increase revenues such as feed in tariff, accelerated depreciation, and tax breaks are widely employed by Asian countries. Performance of countries on rationalization and phasing-out of fossil fuel subsidies is at variance. Emission taxes such as carbon tax, which are known to have adverse distributional effects in general, are not widely implemented. Even though the tax on natural resources extraction is an effective tool in containing natural capital loss, it is yet to be widely used despite of the fact that natural resources extraction is happening at an unprecedented rate in the region.

If the entire region is considered, the current pace of transition to a green economy is highly concentrated and slow-moving. With ongoing pace, the actual transition of the region as a whole to a green economy may not happen anytime soon. Green economy cannot be achieved automatically through the market mechanism and countries in the region are yet to realize that fact. Furthermore, Asian countries do not seem to be prepared to incur short-term costs in order to reap long-term benefits. Countries in the region are yet to acknowledge a price gap between current market price and the real cost of natural resources use and ecosystem services. As a result, natural resources extraction is happening at an alarming pace. Forests in the region are being destroyed at an alarming rate of nearly $1 \%$ per year or more than one million hectares per year. Cambodia, Laos, Myanmar, Thailand and Vietnam will lose $34 \%$ of their remaining forest cover by 2030 unless they improve management of natural resources and transition toward a green economy (WWF, 2013). Forests are most likely to be eliminated first $\mathrm{n}$ tropical Asia, where the rates are high and forest areas small, and then in West Africa (Houghton, 2005). Even though the market has an important role, only government can lead the systematic transition either through strict regulation or through fiscal incentives or through the combination of both, and close these gaps (ESCAP, 2012). Such approach is warranted as the choice Asian countries face today is not between 'getting prices right' and 'getting the institutions right' but 'getting the system right', with careful representations of and adaptations to local and global contexts under which green transition is to be made. 'Getting prices right' strategy may fail if implemented through ineffective governance structure, behavioral rigidities, agency problem, and other market imperfections such as missing markets and institutions, coordination failures, and lack of credible price signals. Such conditions prevent prices from delivering desired outcome of green growth.

Public finance theory is a guiding force to determining how public finance should be raised for providing public goods or near public goods. In general, public authorities have two financing choices- first is fiscal instruments such as raising taxes, fees or user charges; and second is public borrowing. The accepted principle is to keep borrowing for public investment as long as social rate of return on investment is higher than cost of arranging funds (Ismihan \& Ozkan, 2008). Fiscal instruments have a central role to play for a transition to a green economy through robust and fair economic growth. The fiscal reforms have emerged as even more promising set of policy tools for a developing country given the critical and urgent need of poverty reduction through sustainable development in these countries. Since eco-efficiency of production is not sufficient for a transition to a green economy, there is also need to shift towards sustainable consumption. It is highly likely that as income goes up in developing countries, unsustainable consumption spreads rapidly and will be difficult to reverse. This 
highlights the urgency of a developing country to avoid the trap of energy and resource intensive lifestyles by making sustainable choices in the early stage of development (ESCAP, 2012). Given the magnitude of required financing for transitioning into green economy, public borrowing alone will not be sufficient to shift the current economic equilibrium to green pathway. Tightening of fiscal constraints and bridging fiscal deficits may be necessary.

\section{Barriers towards the use of Fiscal Instruments}

Despite of all the promises associated with the adoption and implementation of fiscal instruments, there considerable barriers (see table 2) that need to be addressed for these instruments to achieve their fullest potential and help Asian countries transition to a green economy. A thorough understanding of all the aspects of fiscal instruments along with a deeper knowledge of socio-technique regime and political economy of the host nation are required for successful implementation of the fiscal instruments.

\subsection{Distributional effects}

Policy makers should be well aware of possible adverse distributional consequences of the use of fiscal instruments and come up with ways to adequately address adverse distributional impacts. Quality and distributional impact of green transition, induced by fiscal instrument, matter from social welfare point of view. The transition is not an end in itself but an alternative means to provide opportunities to everyone to enhance their own subjective well-beings. Some of the fiscal instruments such as tax on energy or removal of harmful fossil fuel subsidy are often considered to be regressive in nature, because these taxes impose higher additional burden to the low income households than any other income group. Removing fuel subsidies results in an increase in energy price and induces greater hardship for poorer households. Hence, even though fossil-fuel subsidies are an inefficient means of protecting the incomes of the poor, their removal will have to be replaced by targeted pro-poor policies that can contribute to poor households' consumption and expenditure on essential expenditures. Fiscal instruments-induced adverse welfare impacts can and should usually be offset through some carefully designed adjustments in fiscal policies or instruments. Conditional cash transfers, refundable tax rebates, income based user charge, revenue recycling, reduced consumption volatility, skill development and job creation can alleviate hardship on the poor households (Timilsina \& Dulal, 2011). Indonesia has been successful in removing harmful subsidy in energy through a well-informed targeted cash transfer program to compensate the poor people for the fuel price hikes. The program was very well publicized from public television and radios to inform the target group. It was designed in such a way that payments were made to the female household heads that agreed to use the fund in health and education (GIZ, 2013; Hutagalung et al., 2009). In the United States, changes to income tax credits and social security payments are largely successful in mitigating the adverse distributional consequences induced by carbon tax (Metcalf, 2007). The Netherland uses carbon tax revenue to reduce the general burden to consumers and businesses (Koowattanatianchal, et al., 2009). 


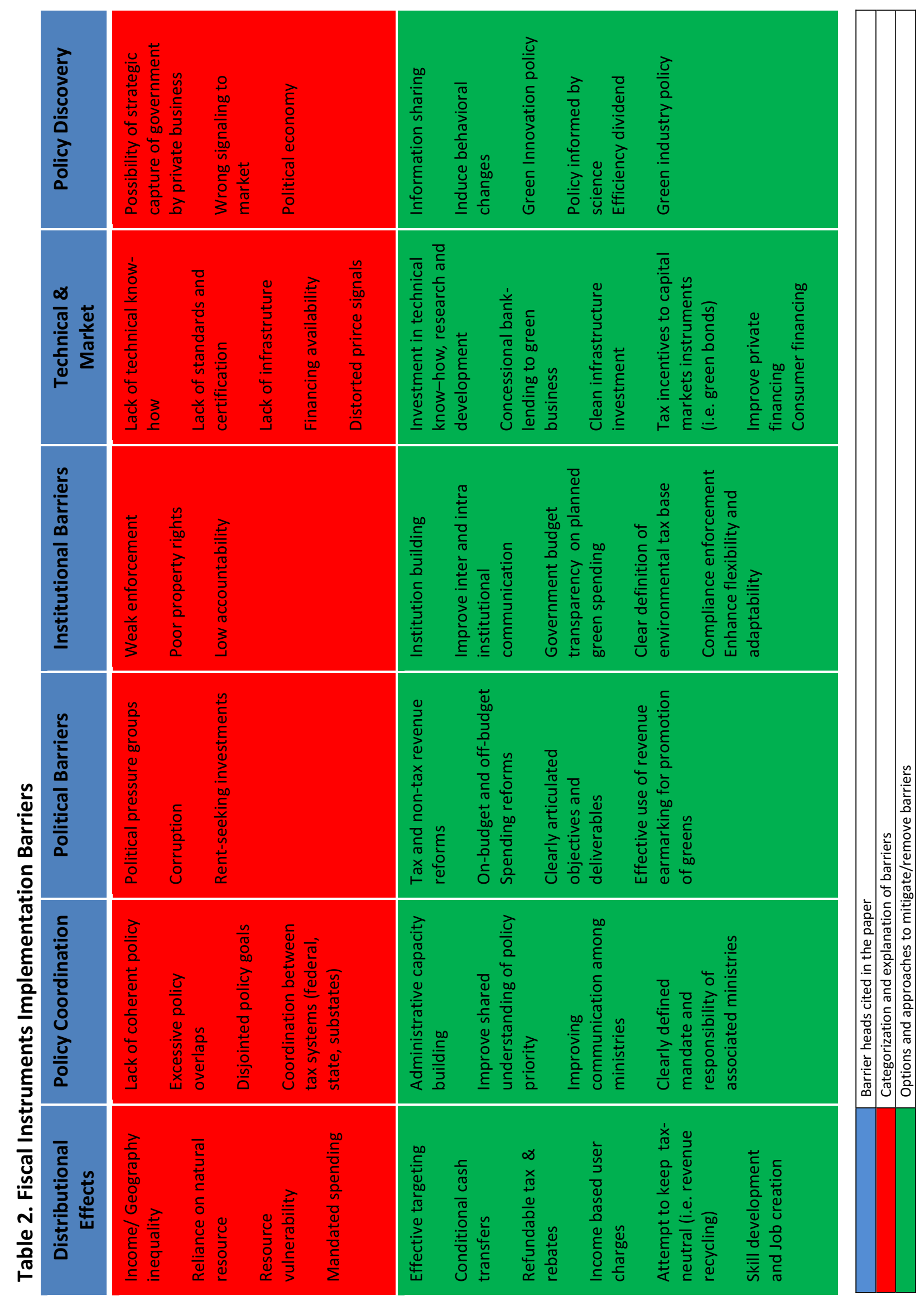




\subsection{Policy Coordination}

In many Asian countries, lack of policy coordination is one of the major barriers to a transition to green economy. For instance, even in emerging economy like Thailand, policy coordination remains a key challenge to achieve greater energy efficiency (World Bank, 2011). Horizontal policy integration also suffers from a lack of coordination across India's highly fragmented ministerial structure (Planning Commission, 2007). Fiscal instruments do not work best in isolation. Lack of coherent policy, excessive policy overlaps, disjointed policy goals, coordination between tax systems (federal, state, substates) could adversely impact effectiveness of fiscal instruments and their contribution towards green economy transition. Complementary mix of fiscal instruments is likely to work better than "stand alone" tools. For example, an increase in the cost of environmentally harmful goods as a result of environmental tax may reduce the supply of labor (Goulder, 1995). Thus, it warrants more cautious use of fiscal instruments particularly in the developing countries where the fiscal framework is highly distortionary in nature. Depending upon the institutional and capacity, lack of policy coordination can be resolved by initiating administrative capacity building, improving shared understanding of policy priority, effective communication among ministries, clearly defined mandate and responsibility of associated ministries, etc. The aforementioned measures will work best in countries, where the institutional and human capital relatively robust. In least developed countries in Asia, where institutional and human capitals is low or have regressed over the years, the policy coordination may have to be supported by concrete institutional and operating arrangements like monetary and fiscal coordination board. In the least developed countries in the region, the concept of such policy coordination might have to be introduced through policy reforms.

\subsection{Political Barriers}

Many Asian countries' transition to a green economy is stalled, because of the lack of political unwillingness to walk away from fossil fuel dependency, carbon-intensive infrastructure development, and energy-intensive industrialization, and highly inefficient urban development. Political pressure, corruption, and rent-seeking investments have led to political indecisiveness, when it comes to dealing with removal of harmful fossil fuel subsidies and promoting renewables that are some of prerequisites for transitioning to a green economy. For example, in several countries across the region (see table 1, annex 1), instead of coming up with a variety of government interventions such as zero interest loans, rebates, tax credits that could speed up the installation and use of renewables and energy saving measures, perverse incentives that promote the use of fossil fuel continues unabated. Subsidies on energies and other resource intensive goods and services are common in the Asian countries. Subsidies on fossil fuels exceed 5 per cent of GDP in many Asian countries. In 2011, Fossil fuel subsidies amounted to 28, 23, 19, and 17 percent of GDP in Uzbekistan, Turkmenistan, Iraq, and Iran (Bruvoll \& Vennemo, 2014). China, India, and Indonesia-each have energy subsidies in excess of \$10 billion per year. The total cost of liquid petroleum gas (LPG) subsidy to the state oil companies and the government amounted to almost $\$ 1.7$ billion in the first half of $2007 / 08$ fiscal year. An estimated $76 \%$ of this subsidy is allocated in the urban areas, where LPG subsidies end up 
benefiting richer households (UNEP, 2008). Removal of environmentally harmful subsidies is politically unpopular particularly in Asia. Subsidies are so entrenched or disguised within countries' political and economic systems that people almost feel that they are entitled to cheap fuel. Subsidies are highly politicized and protests against the price hikes in fuels are frequent in Asia. The backlash as a result of subsidy removal may even result in overthrow of the government in power. This could happen through riots in protests or replacement of rulers through elections. It will take some time and a great deal of political will to identify and implement the appropriate multilateral disciplines necessary to root all of them out. The prevailing burden of harmful subsidies can be relieved if the governments in the region make an effort to devise ways that can adequately address concerns of social groups that are most impacted by the removal of fossil fuel subsidies. Tax and non-tax revenue reforms, on-budget and off-budget spending reforms, clearly articulated objectives and deliverables, effective use of revenue earmarking for promotion of greens can ease existing political barriers that are stifling efficient and adequate pricing of energy in the region. Evidence suggests that carefully designed targeted programs with bold political actions can make the reform possible. In December 2010, the Iranian government successfully implemented bold economic reforms to phase out subsidies to energy products and replace them with targeted cash transfer as compensation for rising energy prices. Similar program as instituted in Indonesia as well. Cashbased compensation like the ones administered in Indonesia and Iran could very well work in least developed countries in the region. Emerging economies, with a relatively robust taxation system may use the progressive income tax schedule for redistribution. A marginal tax of 0 per cent for low-income groups and up to a maximum 50 percent for rich families could alleviate the adverse effects resulting from higher fuel taxes or removal of subsidies on fossil fuels.

\subsection{Institutional Barriers}

Weak enforcement, poor property-rights regime, and low accountability have all contributed to poor adoption and widespread use of fiscal instruments in the region. In many countries, environmental legislations are often poorly developed, inconsistent, and overlap with other sector-based legislations. For example, the institutional framework for environmental governance remains fairly weak, making policy implementation a particular challenge. For instance, in China, the Ministry of Environmental Protection's (MEP) mandate remains relatively weak and overlaps with those of other sector ministries (Qiu \& Li, 2009). In India, commandand-control approach although no longer match the complexity of the Indian economy and the multiple sources of environmental pollution is yet to be replaced by fiscal instruments. Likewise, despite the transition from a socialist command economy to a market-driven model, the new environmental policy framework in Vietnam still remains dominated by a highly centralized "command-and-control" structure (Mitchell, 2006). As Command and control approach still dominates environmental governance, fiscal and market-based instruments have a limited role to play. The charges for environmentally harmful activities are too low to provide any relevant incentive to reduce emissions in China, Indian, and Vietnam (Quitzow, 2011). For instance, a 25 percent rebate on water cess is provided to firms that meet the required 
standards regulating water use in India (OECD, 2006b). The tax rebate is not enough to provide any significant incentive for additional investments (Kumar, 2009).

Countries in the region need to: invest in institutional capacity building, improve inter and intra institutional communication, ensure budget transparency on planned green spending, clarify environmental tax base definition, improve compliance enforcement, and enhance institutional flexibility and adaptability. A clear governance structure operating under clearly laid out rules and conditions, accountability framework, and political independence are required for efficient functioning of fiscal instruments, timely disbursement of tax revenue for promotion of green economic activities, and monitoring. The biggest governance risk in green fiscal space is the possibility of tax revenues being treated as political device used to achieve short term political gains at the expense of achieving the original objective for which the tax was designed and implemented. Opaque institutional functioning, decision-making entrenched in politics, and complicated and convoluted flow of communication and monetary resources undermine the performance of fiscal instruments and adversely impact revenue collection and recycling.

\subsection{Technical and Market}

Lack of technical know-how, standard and certification, and infrastructure are hindering the adoption and use of fiscal instruments in Asia. In addition, there are market barriers such as lack of financing and distorted price signals that add another layer of complexity to the wider use of these instruments. Given the comparatively low technical know-how, it is difficult for countries to choose the right instruments, determine correct tax rate, and understand how market imperfections could potentially affect the implementation the chosen fiscal instruments. Administering of fiscal instruments across multiple jurisdictions - with differing procedures, rules, definitions, and levels of corruption, competence, and willing (or unwilling) compliance further complicates the problem. Investment in human capital, concessional banklending to green business, clean infrastructure investment, tax incentives to capital markets instruments (i.e. green bonds), improvement in private and consumer financing can help ease the aforementioned technical and market barriers. Technical, financial, and organizational intermediation may be needed to facilitate large scale diffusion of renewable technologies, as except for hydro-power, other renewable energy technology is relatively new to the region. Technical intermediation would basically include improving the technical options and capacity through research and development activities and importing the technology and know-how it is required to supply the necessary goods and services. Financial intermediation, in particular commercial banking, has a significant positive effect on the amount of renewable energy produced. The impact is especially large when non-hydropower renewable energy such as wind, solar, geothermal and biomass are considered. Organization intermediation includes putting in place the necessary infrastructure and getting the incentives right to encourage owners, contractors, and financiers of renewable energy (Brunnschweiler, 2010). In order to support renewable energy, for example, South Korea promotes feed in tariff tax exemptions for dividends in combination with long term loans for manufacturing facilities. In many countries, 
especially the least developed one in the region, removing supply side constraints is not enough. Households, especially the poor ones, will need some sort of support for them to be actually be able to benefit from fiscal instruments. For example, many fiscal instruments such as tax credits or exemptions focus on achieving energy efficiency (Gunningham, 2014) may not be any help to the vast majority of poor that are outside the tax umbrella. Like in the case of LPG subsidy in India, it will again be the well-off households that benefit from such tax credits or exemptions. High income households will end of benefiting from tax credit for purchases of energy efficient appliances. Periodic support towards the purchase of energy efficient appliances such as bulb, fan, iron that poor households mostly use along with subsidized energy or cash transfer to help them cover energy costs is necessary if large scale energy efficiency gains are to be achieved in the region.

\subsection{Lack of Policy Discovery and Discipline}

Possibility of strategic capture of government by private business, wrong signaling to market, and political economy could all jeopardize the effective use of fiscal instruments. An appropriate green fiscal policy needs to make room for learnings by public officials and institutions to accommodate quality and flow of information, uncertainty associated with green innovation and technologies, and significant amount of interaction between public authorities and private sector. Such approach views fiscal policy and products as a process of discovery, by the government itself, no less than private businesses and households. What this does is shift attention to learning where constraints and opportunities lie and respond together, rather than to whether national budget should employ a specific set of predetermined fiscal instruments such as concessional loan, subsidies, tax concessions, etc (Rodrick, 2014). Lack of principled discipline with utmost clarity in objective of a specific green fiscal policy has also appeared as obstacle to successful implementation of effective green fiscal system. Many times, ex-ante specification of a policy objective is not stated, which in turn makes the ex-post evaluation of the fiscal instrument highly arbitrary, and does not correctly inform policymakers whether the policy is working or needs a rethink. Political functionaries may use the arbitrary evaluation to their advantage by clubbing multiple objectives associated with the policy program which makes the policy evaluation even more difficult and arbitrary.

\section{Conclusion}

Adoption and use of fiscal instruments in Asia is happening, but at a slower pace and not at a sufficiently large scale necessary to facilitate transition to a green economy. Despite wellestablished theoretical foundations and examples showing that fiscal instruments facilitate transition to a green economy, most Asian countries are yet to reshape their policies and institute fiscal instruments to promote eco-innovation and green business. Only a few fiscal instruments are in use and their use has been very sporadic. Rather than using suit of fiscal instruments, countries seem to prefer certain instruments more than others. Available evidence suggests that countries mostly prefer user fees, fuel taxes, and subsidies, and tax incentives. Emission tax and tax on natural resource extraction are yet to be widely used (see 
table 1, annex 1) even though rising emissions and natural resources extraction are one of the significant barriers to transition. While user fee, fuel tax, and subsidy are adopted and used irrespective of developmental status, subsidy, emission tax and tax on natural resources extraction are only used in developed and developing countries in Asia. Despite of ongoing rapid increase in emissions and loss of natural resources, emission tax and tax on natural resources extraction are yet to be put in place in the least developed countries. The reason behind the widespread use of user fees and charges could be its revenue generating potential, simple design and implementation cycle, and easier revenue hypothecation possibility. Revenue generated through user fees could be substantial if implemented at a sufficiently large scale. For instance, user fees constitute significant portion of total non-tax revenue in China and are largely collected by local and provincial governments. Even though this fiscal instrument creates a strong incentive for resource-efficiency and cleaner technologies, it has so far been mostly used in managing waste water, solid waste, payment for dumps, and waste collection charges, etc. Congestion charging, which is basically a user fee system, if used at a sufficiently large scale in rapidly urbanizing countries such as China, India, Indonesia, and Bangladesh, would not only help ease traffic congestion, but also contain growing energy use and associated emissions. Congestion charge, introduced in London, for example, led to the reduction in total vehicle-kilometres by $12 \%$ and car traffic by $30 \%$. It also led to increase in moped and motorbike travel by $10-15 \%$, bicycle travel by $20 \%$. Bus journey time reliability increased by about 60 percent (Transport for London, 2004). In rapidly growing economies like India, China, Indonesia, Thailand, Malaysia, where private vehicle ownership has skyrocketed in the past decades and resulted in an urban gridlock, implementation of congestion charging system is necessary to enhance mobility, reduce energy use and associated emissions, and most importantly ensure transition to a urban green economy.

Fuel tax is another common instrument used in Asia even though the main objective behind its use revenue generation. Irrespective of policy objectives, the use of fuel tax does contribute towards the transition to a green economy as it plays an important role in reducing energy and transport sector externalities. The level of environmental externalities would be higher in the absence of fuel tax. Evidence suggests that for every $1 \%$ increase in the fuel tax, vehicle miles traveled (VMT) could be reduced by $0.042 \%$ (Hirota et al., 2003). However, there is only so much that fuel tax as a fiscal instrument can achieve if used in isolation. In countries with megacities, where rising urban emissions have led to the serious deterioration in ambient air quality, the use of fuel tax alone is insufficient to contain urban air emissions. Emission tax needs be used along with the fuel tax to contain rising emissions, including greenhouse gases. Fuel and emission taxes tend to be the most effective policy instruments when it comes to reducing $\mathrm{CO}_{2}$ emissions (Acutt and Dodgson, 1997; and Sterner, 2006). Furthermore, it makes economic sense to explore synergies between various fiscal instruments. Countries can dramatically save costs by adopting a smart mix of fiscal instruments to reduce air pollution and greenhouse gas emissions even if the goal is to achieve ambient air quality. Evidence suggests that compared to the most cost-effective way for halving negative health impacts from air pollution using only air pollution control measures, using measures to lower air pollution and greenhouse gas emissions simultaneously is much more cost-effective (Amann et al., 2010). Another problem associated with the use of fuel tax as a fiscal instrument in Asia is that it is not 
discriminatory. Fuel tax needs to be discriminatory in order to yield greater benefits. While fuel used for private vehicles should be taxed, fuels used for public transportation should not. In the absence of discretionary taxation, substitution of high emission private transportation with low emission public transportation will not occur.

When it comes to transition of Asia, as a region, to a green economy is concerned, use of few fiscal instruments here and there is not the answer. Ongoing rapid urbanization, industrialization, infrastructure development, and rising energy use and associated emissions warrants the use of a portfolio of fiscal instruments that best suit each country's specific circumstances. For example, fuel and emission taxes would be more efficient options for reducing fuel consumption and $\mathrm{CO}_{2}$ emissions, whereas congestion charge would be more effective in reducing traffic congestion and associated energy use and emissions. A country with cities confronted with local air pollution and congestion, and emitting significant amounts of $\mathrm{CO}_{2}$, might benefit from the use of suit of taxes and charges: fuel, emission, and congestion. Hence, the choice of appropriate fiscal instruments should largely be based on upon the country's energy use and emission profile, available infrastructure, existing institutional and human capacity, tax base and regime, and revenue recycling mechanisms, etc. 


\section{References:}

Acutt, M. Z. and Dodgson, J. S., (1997). Controlling the environmental impacts of transport: Matching instruments to objectives. Transportation Research Part D: Transport and Environment, 2: 1, 17-33.

Amann, M., Bertok, I., Borken, J., Chambers, A., Cofala, J., Dentener, F., et al. (2010). GAINS ASIA: A tool to combat air pollution and climate change simultaneously. Laxenburg, Austria: International Institute for Applied Systems Analysis.

Asian Development Bank (ADB) (2011). Key Indicators for Asia and the Pacific. Asian Development Bank, Manila, Philippines.

Bhattacharyay, B. N., Kawai, M., \& Nag, R. (Eds.). (2012). Infrastructure for Asian connectivity. Edward Elgar Publishing.

Bruvoll, A., \& Vennemo, H. (2014). Reform of environmentally harmful subsidies: distributional issues. Paying the Polluter: Environmentally Harmful Subsidies and their Reform.263-280.

Brunnschweiler, C. N. (2010). Finance for renewable energy: an empirical analysis of developing and transition economies. Environment and Development Economics 15,241-274.

Chen, Josua (2009c). Renewable Energy in China. A Necessity, Not an Alternative. Knowledge@Wharton.

Dargay, J., Gately, D., and Sommer, M. (2007). Vehicle Ownership and Income Growth, Worldwide: 1960-2030. http://www.econ.nyu.edu/dept/courses/gately/DGS Vehicle\%200wnership 2007.pdf

Energy Information Administration. 2001. International energy outlook 2001. Washington, D.C.: U.S. Department of Energy, Office of Integrated Analysis and Forecasting.

Washington, D.C.: U.S. Department of Energy, Office of Integrated and International Energy Analysis.

GIZ. (2013). Case studies, environmental fiscal reforms. Available at http://www.giz.de/expertise/downloads/giz2013-en-environmental-fiscal-reform-casestudies.pdf

Goulder, LH(1995). Environmental taxation and the double dividend: A reader's guide, International Tax and Public Finance,2,157-184. 
Gunningham N.(2014). Regulation, Economic Instruments and Sustainable Energy. Climate and Environmental Governance Network (CEGNet), Working paper (29).

H. Hui \& B. Anup (2011). A Review and Comparative Analysis of Fiscal Policies Associated with New Passenger Vehicle $\mathrm{CO}_{2}$ Emissions. The International Council on Clean Transportation.

Houghton, R.A. (2005). Tropical deforestation as a source of greenhouse gas emissions. In P. Moutinho and S. Schwartzman (eds). Tropical deforestation and climate change. IPAM and Environmental Defense, Belem, Brazil and Washington, DC. 132 pp.

Hutagalung, S, Sirojuddin Arif and W Suharyo (2009).Problems and challenges for the Indonesian conditional cash transfer programme, Keluarga Harapan, Jakarta.

International Energy Agency (2012). Analysis of the Globally Installed Coal-Fired Power Plant Fleet. Paris: IEA

Ismihan, M \& Ozkan, G., (2008). Golden Rule of Public Finance: APanacea?, Discussion Paper in Economics No. 2008/19, Department of Economics and Related Studies, University of York, York.

Koowattanatianchai, N., Charles, M. B., And Ian Eddie, I (2009). Accelerated Depreciation: Establishing a Historical and Contextual Perspective. Paper prepared for Asia-Pacific Economic and Business History Conference 2009, Gakushuin University, Tokyo.

Kumar, S. and Managi, S.(2009). The Economics of Sustainable Development. The Case of India, Heidleberg: Springer.

Mathews J.A.(2012). Green Growth Strategies -Korean Initiatives. Futures 44: 761-769.

Metcalf, GE(2007). A Proposal for a US Carbon Tax Swap: An Equitable Tax Reform to Address Climate ,Washington DC.

Mitchell, C. L. (2006). Beyond barriers: examining root causes behind commonly cited Cleaner Production barriers in Vietnam. Journal of Cleaner Production, 14, 1576- 1585.

N. Wang, Y.-C. Chang (2014). The Development of Policy Instruments in Supporting Low carbon Governance in China. Renewable and Sustainable Energy Reviews 35: 126-135.

OECD (2014). OECD Economic Outlook, Vlo.2014/1, OECD Publishing. http://dx.doi.org/10.1787/eco outlook-v2014-1-en

OECD (2006b). Environmental Compliance and Enforcement in India: Rapid Assessment.'OECD.

Pandey, R., Bali, S., \& Mongia, N. (2014). International Clean Energy Funds: A Review. In the National Clean Energy Fund of India (pp. 15-26). Springer India. 
Pandey, R., Bali, S. \& Mongia, N. (2013). Promoting effective utilization of the National Clean Energy Fund. New Delhi: Shakti Sustainable Energy Foundation

Pew Center Coal Initiative Retrieved at

http://www.c2es.org/docUploads/Pew\%20Climate\%20Coal\%20Project\%20Summary-

May\%2023-06.pdf

Planning Commission. (2007). Eleventh Five Year Plan 2007-2012. Inclusive Growth. Volume 1: Inclusive Growth. Delhi: Planning Commission, Government of India.

Punte, S. (2012). Growing cities, healthy cities. Clean air Asia. http://www.baq2012.org/assets/Uploads/Sophie-Punte-Opening-Plenary-BAQ2012-FINAL6.pdf

Qiu, X., \& Li, H. (2009). China's Environmental Super Ministry Reform: Background, Challenges, and the Future. The Environmental Law Reporter 2(2009).

Quitzow, R., Bär, H., \& Jacob, K. (2011). Asia at a crossroads: new trends in environmental governance in India, China, Vietnam and Indonesia. Environmental Policy Research Centre (FFU), Freie Universität Berlin.

Sawhney, A \& Rahul M. (2014). Examining the regional pattern of renewable energy CDMpower projects in India. Energy Economics 42, 240-247

Schmid, G. (2012). The development of renewable energy power in India: Which policies have been effective?. Energy Policy 45, 317-326

Shekhar H. et al. (2013). Low Carbon Industrial Growth in India. TERI BCSD \& YES

Bank Ltd.

Statistical Yearbook for Asia and the Pacific 2012.

Sterner, T., (2007). Fuel taxes: An important instrument for climate policy. Energy Policy, 35, 6, 3194-3202.

TERI-NCSC-CUFE-ZU-UNDP (2014). Low Carbon Development in China and India: Issues and Strategies. Advance Publication.

Timilsina G.R. and Dulal H.B.(2010). Urban Road Transportation Externalities: Costs and choice of policy instruments. World Bank Res. Obs.(2011) 26(1):162-191.

Transport for London (2004). Congestion Charging: Update On Scheme Impacts And Operations, Transport for London (www.tfl.gov.uk/tfl/downloads/pdf/congestion-charging/cc12 monthson.pdf). 
UNEP, 2009. Global Green New Deal: Policy Brief. Geneva: UNEP. Available online at < www.unep.ch/etb/publications/Green\%20Economy/UNEP\%20Policy\%20Brief\%20Eng.pdf

UNEP, 2008. Reforming energy subsidies: Opportunities to contribute to the climate change agenda. Nairobi: UNEP

United Nations. 2001a. State of the environment in Asia and the Pacific: 2000. New York: United Nations Economic and Social Commission for Asia and the Pacific and Asian Development Bank.

World Bank.2014. World Development Indicators database. Washington, D.C. http://data.worldbank.org.

World Bank (2011). Thailand: Economic Monitor. Thailand: World Bank

Wong, S. (2012). Overcoming obstacles against effective solar lighting interventions in South Asia, Energy Policy 40, 110-120 17 (1).

World Resources Institute, (2005). Navigating the Numbers Greenhouse Gas Data and International Climate Policy. Washington DC: World Resources Institute.

WWF (2013). Ecosystems in the Greater Mekong Past trends, current status, possible futures. 


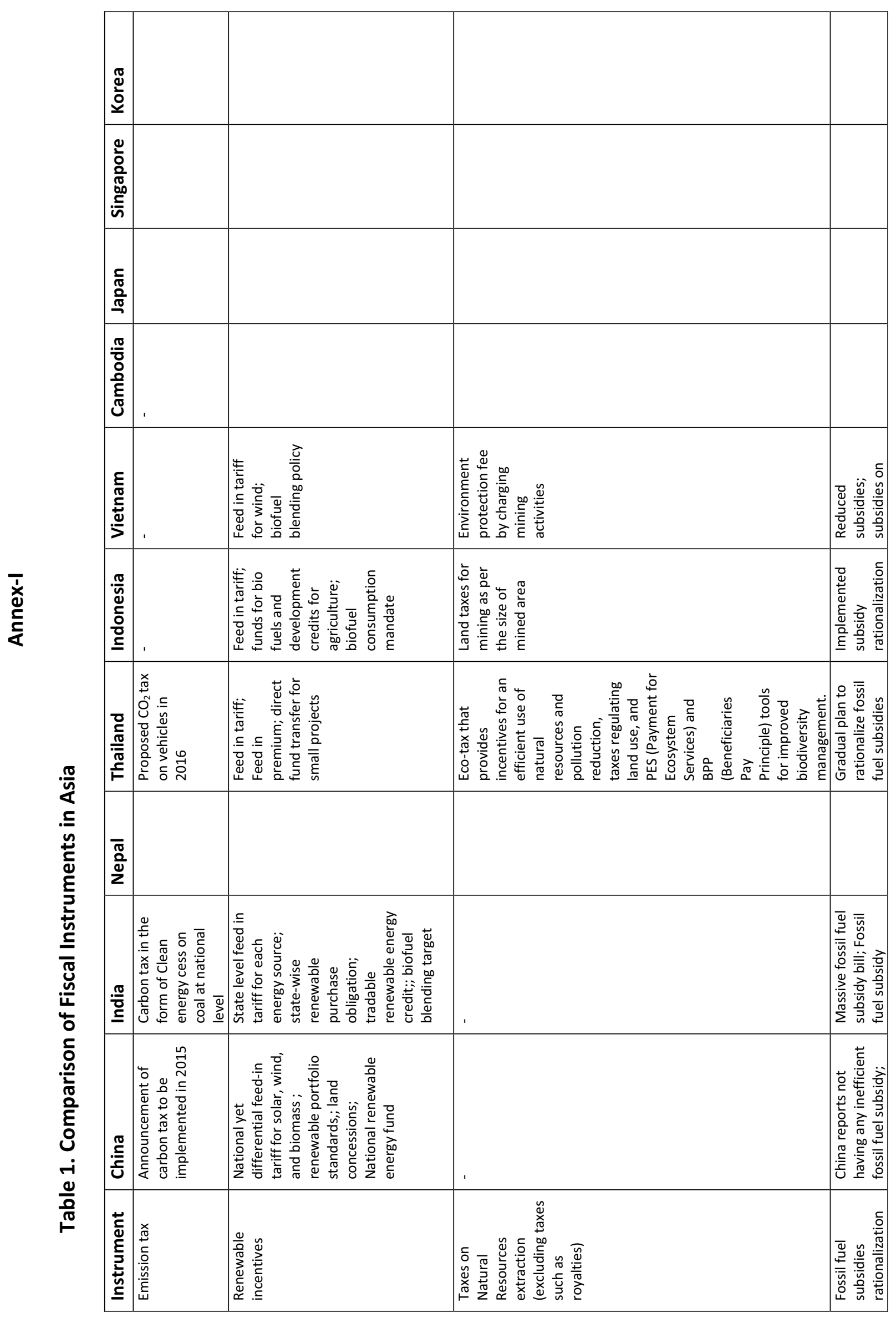




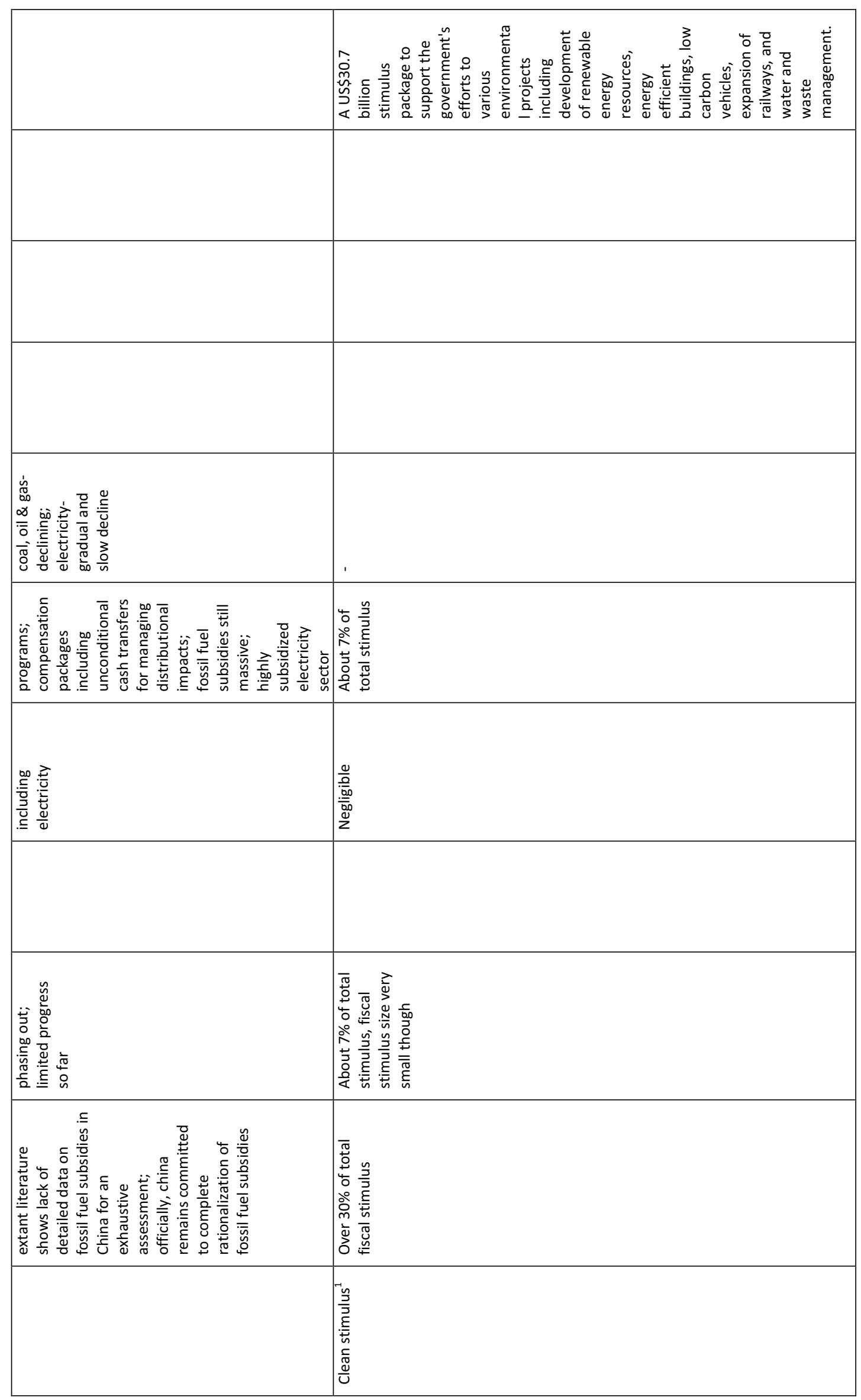




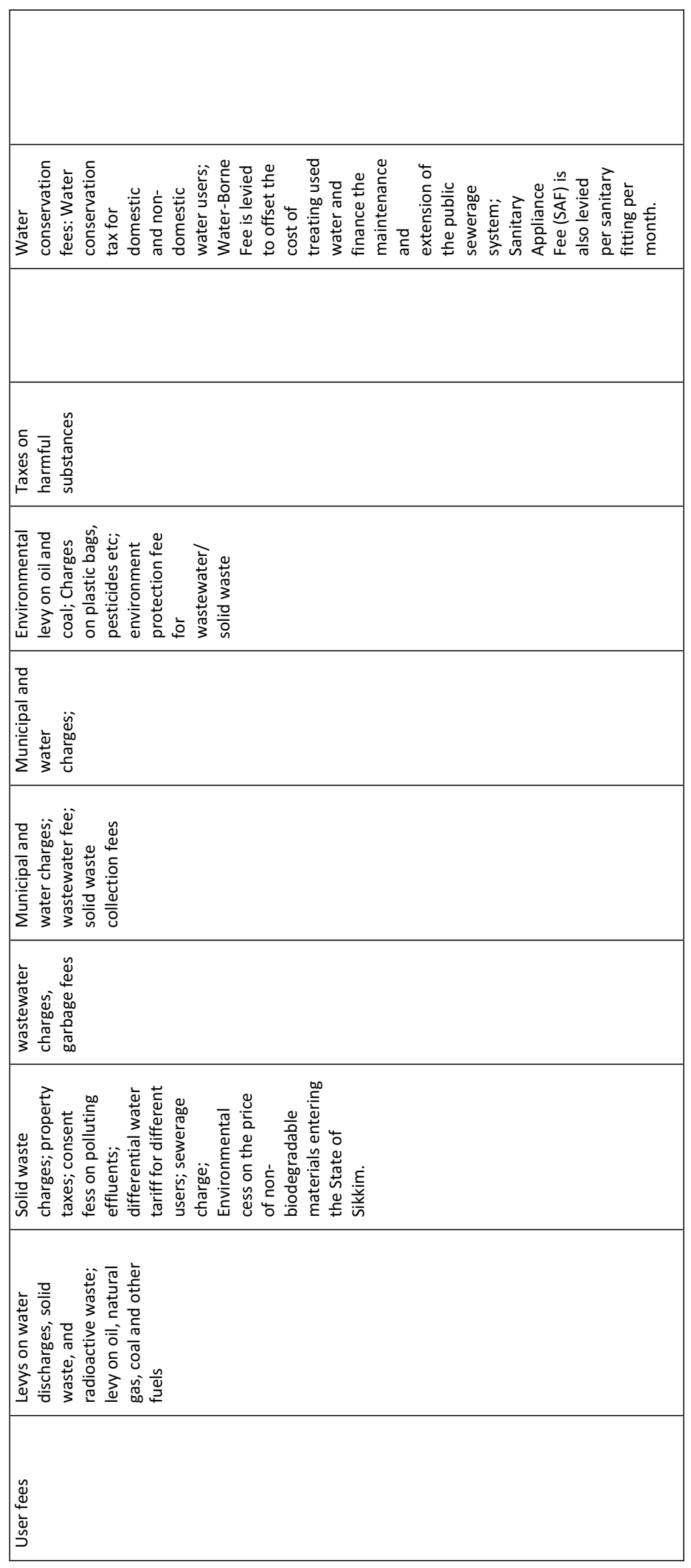




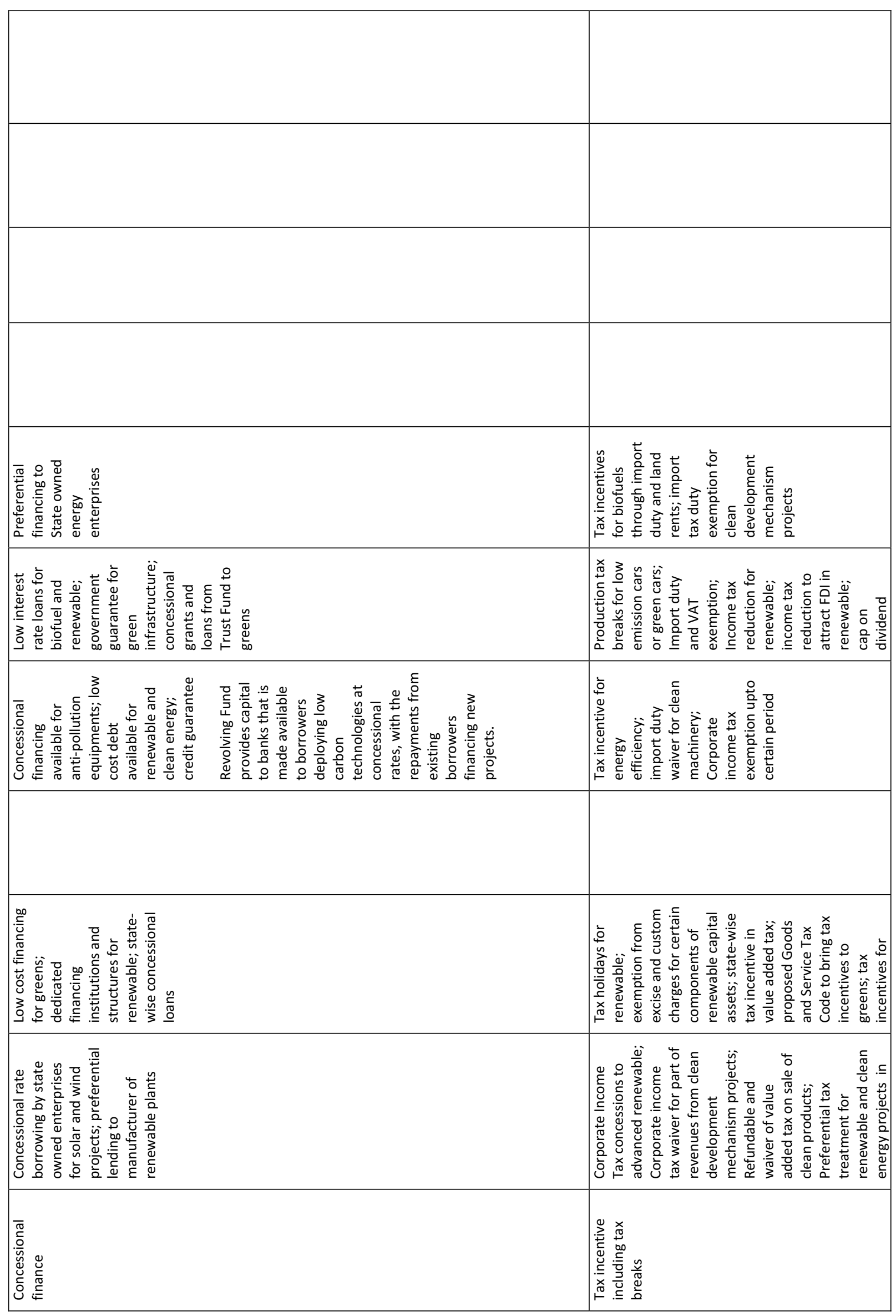




\begin{tabular}{|c|c|c|c|c|}
\hline & & & & 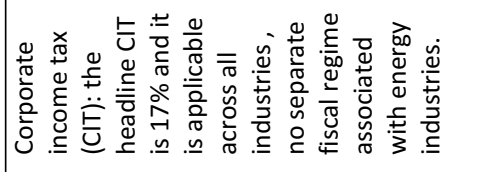 \\
\hline & 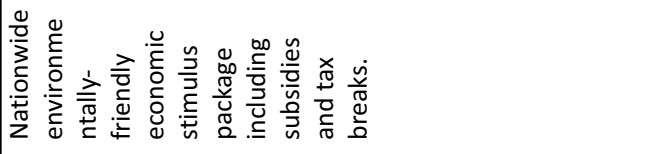 & & & 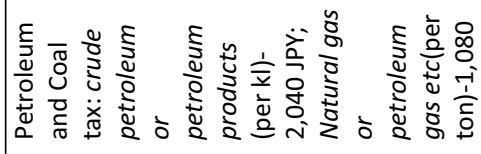 \\
\hline & | & 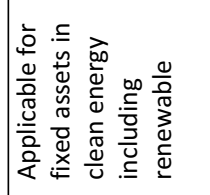 & 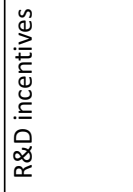 &  \\
\hline \multirow[t]{3}{*}{ 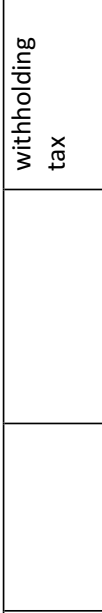 } & 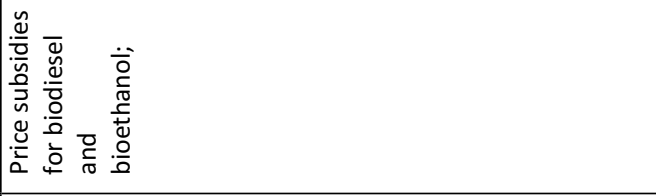 & 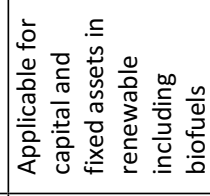 & 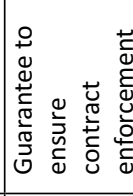 & 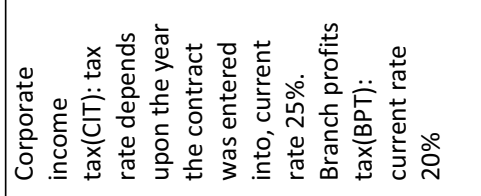 \\
\hline & 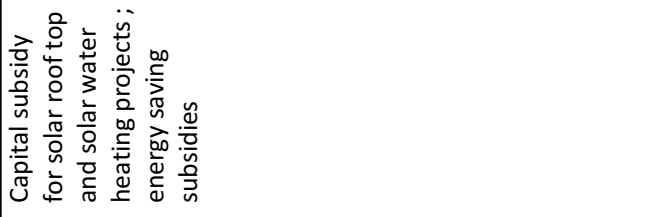 & . & & 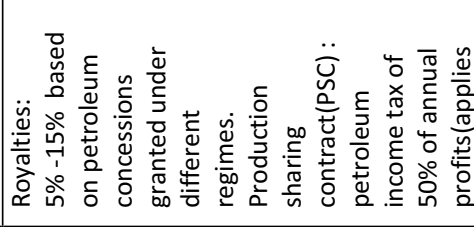 \\
\hline & 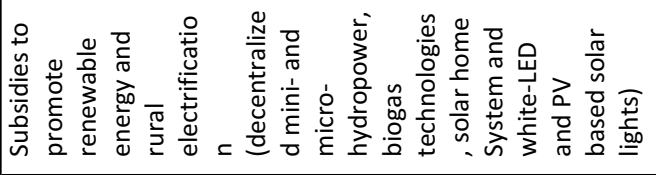 & & & \\
\hline 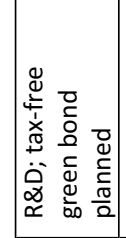 & 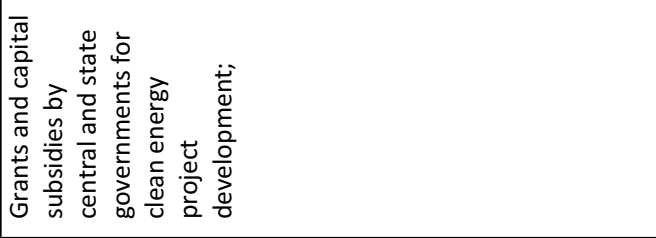 & 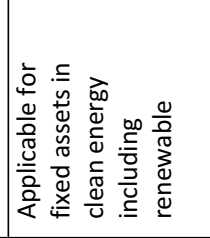 & 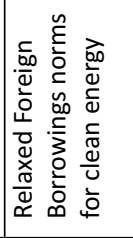 & 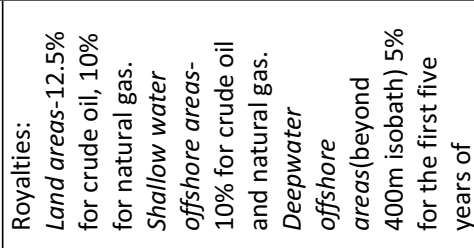 \\
\hline 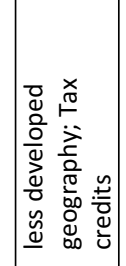 & 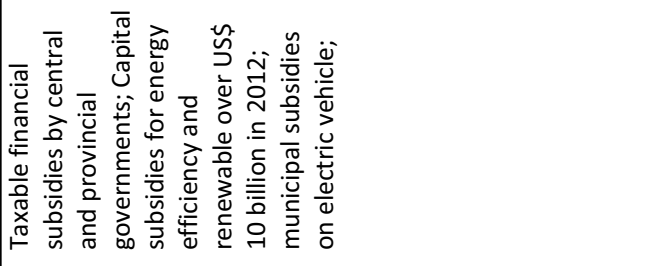 & 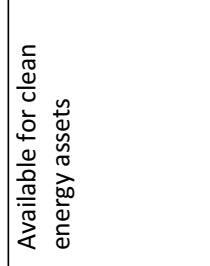 & 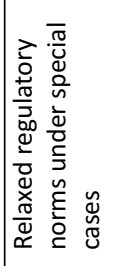 & 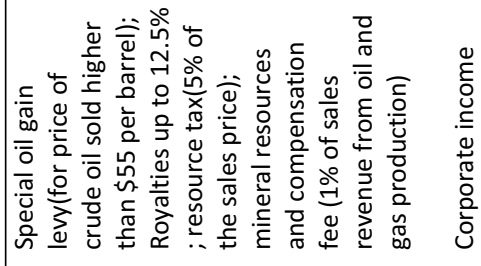 \\
\hline &  & 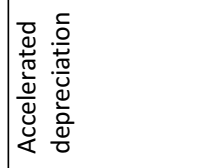 & 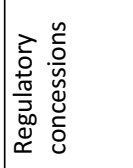 &  \\
\hline
\end{tabular}


